\title{
Facebook, Twitter Activities Sites, Location and Students' Interest in Learning
}

\author{
J. N. Igbo ${ }^{1}$, Ifeyinwa Ezenwaji ${ }^{1}$ \& Christiana U. Ajuziogu ${ }^{1}$ \\ ${ }^{1}$ Department of Educational Foundations, Faculty of Education, University of Nigeria, Nsukka, Nigeria \\ Correspondence: J. N. Igbo, Department of Educational Foundations, Faculty of Education, University of \\ Nigeria, Nsukka, Nigeria. E-mail: janetigbo@yahoo.com
}

Received: September 6, 2017

Accepted: October 24, 2017 Online Published: January 26, 2018

doi:10.5539/ies.v11n2p133

URL: https://doi.org/10.5539/ies.v11n2p133

\begin{abstract}
This study was carried out to ascertain the influence of social networking sites activities (twitter and Facebook) on secondary school students' interest in learning

It also considered the impact of these social networking sites activities on location of the students. Two research questions and two null hypotheses guided the study. Mean and Standard Deviation were used to answer the research questions, while t-test statistics was applied in testing the null hypotheses. In carrying out the study, the researchers adopted Ex-post Facto research design. The sample of the study consisted of 240 senior secondary school Two (SSS11) students from public schools. Multi-stage sampling technique was used to select 120 students from the urban and 120 students from the rural areas. A 15-item Questionnaire was used in data collection. Cronbach Alpha was used to establish the internal consistency of the instruments. Cronbach Alpha Coefficients values of 0.88 and 0.72 were obtained. The findings of the study indicated that there is a significant influence of students' Twitter and Facebook activities over their interest in learning. Students in urban schools had higher Mean Score interest in learning than those in rural location. The result also indicated that there is no significant difference in the Mean interest ratings of urban and rural students.
\end{abstract}

Keywords: twitter, Facebook, interest, social networking, location, learning, interest in learning

\section{Introduction}

\subsection{Overview of the Problem}

Recently, children of school age have been very much interested in utilizing various forms of social networking sites for their communication. Prominent among these sites is Facebook, followed by Twitter, in terms of patronage across different nations of the world. The youth who are the most active users of these social networking sites use the sites to connect friends, photos, videos and games. While some researchers claim that the use of SNS by students improves their academic achievement (Ovute \& Ovute, 2015). Others argue that it has impacted negatively on the behavior and academic achievement of the learners (Morgan, Grahan, \&Hodges, 2012).

It has been observed that most of the secondary school students in Owerri Education Zone of Imo State especially in the senior secondary schools, no longer take their studies seriously. This may be because, instead of focusing on their studies, they may either be busy chatting with their friends and acquaintances on Facebook or posting an update via Twitter. This ugly trend may distract the students from reading their books or being attentive during the teaching and learning process as they no longer have interest in learning. This is in line with the view of Csikszentmihalyi (1975) Flow Theory.

The origin of research on the flow theory came about when Csikszentmihalyi tried to understand why artists, especially painters, became immersed in their work to the extent that they would disregard their needs for food, water, and sleep. This theory emphasized on holistic sensation that individuals feel when they act with total involvement in activities that they are interested in doing. It implies absorption in a task such that the individual is attracted and carried away by the task being performed. Therefore, Flow theory is relevant to this study because of its emphasis on deep concentration on activities and the consequences of this deep involvement. 


\subsection{Importance of the Problem}

The student who use Twitter and Facebook sites are usually deeply involved in the use of these sites to the extent that they may not think of any other thing including their studies. This deep involvement may, therefore, have negative effect on their academic achievement. This implies that the earlier they are called to order, the better for them in particular and the society as a whole. On the other hand, this deep involvement may enhance students' interest and achievement in learning if they use these sites for academic purposes.

Practically, this study will be of immense benefit to the students, because the findings would help students to appreciate the need for them to take their studies seriously in order to record encouraging academic performance. This study highlights the negative consequences of the students' deep involvement in social networking to the detriment of their studies. It will also enable students to appreciate the importance of using social networking sites to enhance their academic achievements instead of using the sites to waste their time by engaging in fruitless and non-academic activities. The study will help educational planners in making decisions regarding those aspects of social networking sites and activities that would enhance students' interest in learning. Psychologists may find the study very useful, because the findings might help them in formulating more appropriate theories on learning and behavioral patterns among learners. Besides, the results of the study will serve as available data for future researches into the influence of different information and Communication Technology (ICT) tools on students' interest in learning.

Finally, the findings of the study will be of immense benefit to the global community as a whole. This is because if the students are well brought up and guided on the best way to utilize the social networking sites, it is the society and the global community that would benefit from it. These students would eventually join the labor force after graduation to make life worth living for their families in particular, and the society in general. In other words, surfing the internet, especially Facebook and Twitter, may influence students' behavior and interest in learning. Based on this problem therefore, the researchers set out to ascertain the influence of the two major networking sites- Facebook and Twitter on senior secondary school two (SSS 11) students' interest in learning.

\subsection{Dimensions of Interest, Facebook, Twitter and Location}

Apart from disrupting normal flow of classroom activities, social networking such as Twitter and Facebook may also engender interest or lack of interest in learning. Lai (2010) defines interest in learning as personal preferences with regard to learning, which sometimes means that an individual chooses one thing rather than other things and sometimes a positive psychological state occurs during his or her interaction with the circumstances that engender further learning activities. According to Li (2009), in a classroom setting, interest is required to meet students' intellectual as well as emotional needs; interest can never be imposed on an individual by external forces, but a teacher can help increase the learners' interest. Interest in learning may be induced or enhanced by the teacher ( $\mathrm{Li}, 2009)$. This may be done through the use of teaching methods that are learner-centered. This includes such methods that involve the utilization of information and communication technology (ICT) tools such as Facebook and Twitter. On the other hand, learners' interest in learning may be negatively influenced when they preoccupy themselves with ICT tools such as Facebook Twitter thereby disrupting academic activities during the teaching and learning process. In other words, the use of social networking sites such as Facebook and Twitter may influence students' disruptive behaviour and interest in learning. The above views from Lai (2010) and Li (2009) imply that interest has to do with an individual's choice but someone else's activities can arouse another person's interest in a particular phenomenon. Interest in learning, operationally, can therefore be defined as a learner's curiosity or inclination towards a particular aspect of learning.

Current developments in technology has given rise to diverse ways of sending and receiving information among different people across the globe such as Facebook, Fraudster, Twitter, Yahoo Messenger and Skype. Kalra and Manani (2013) are of the view that it is through these sites that people come in contact with friends, seek mates, search for entertainment and participate in political issues. This means that it is possible for a wide range of activities to take place. It is also a platform where people make friends without coming in physical contact with their friends. Akpan, Enobong, and Nsikam (2013) define Twitter and Facebook as platforms on which a range of activities take place as well as locations for interaction among individuals, groups and communities. They observe that Twitter and Facebook do a lot more than just allowing youths to have a profile and a friend's list. They build upon and integrate many communication tools and technologies such as email, messaging, video-sharing and photo-sharing.

Furthermore, Young (2010) defines Twitter and Facebook as the process of finding friends and managing friendships through the internet. Young further explains that people who wish to meet others put up their most 
compelling and attractive presentations through their profile pages. According to Kuss and Griffiths (2011), Twitter and Facebook as virtual communities where users create public profiles, interact with real-life friends and meet other people based on shared interests. Similarly, Arshin (2010) describes these sites as virtual places where people make friends and share information. These social networking sites have an open membership. As soon as one opens an account and uploads his or her data on the profile page, the person is entitled to create a network of friends. However, some Twitter and Facebook platform are specifically designed for mobile phones, some are accessed via computers and others could be accessed using both mobile phones and computers (Nwabueze \& Aduba, 2014). This implies that the use of social networking sites such as Twitter and Facebook, if not controlled, is capable of disrupting students' interest in their academic activities. Alibi (2013) asserts that the internet use as in social networking sites have indescribable power to influence, connect and mobilize youths. Alibi further states that young people in Nigeria are active users of social media and that Facebook is predominantly used for meeting people, chatting and school work.

The reason for the dominant use of Facebook may be because a good number of Nigerian youths have phones with internet access. Azeez (2011) highlights that the use of social networks for social interaction serves as a source of relief to many people, especially those who would not statement confirms the fact that social networking sites especially Facebook and Twitter are visited by so many people as they have been found to be the most popular among other networking sites. Based on this fact, the researcher seeks to ascertain the influence of Twitter and Facebook on secondary school students' interest in learning.

Twitter is one of the most visited social networking sites in different nations of the world. It is a free micro blogging service that allows registered members to broadcast short posts called tweets (Morgan; Graham, and Hodges, 2012). Twitter members can broadcast tweets and follow other users' tweets by using multiple platforms and devices to promote social and intellectual connections among students. It can be used to enhance communication buildings and critical thinking and to extend classroom discussion (A. Ovute \& L. Ovute, 2015).

Interest is a very significant factor that drives students' ability to pay attention to the activities going on in the classroom. According to Chukwu (2002), interest is a persisting inclination to be attentive and enjoy some activities or contents. Interest has been viewed as emotionally oriented behavioral trait which determines a student's urge and vigor to tackle educational programmes or other activities. This means that interest has to do with feelings and emotions towards a particular object. Ogunjimi, Salami and Oyedare (2015) posit that interest has to do with a learner's predisposition to react positively in certain ways towards certain aspect of the environment. This implies that certain aspects of the environment can also make a learner react negatively. In other words, a learner may approach a learning situation with or without interest.

Interest is the feeling that accompanies special attention to an object or class of objects. It involves a sense of concern and curiosity about something; for instance students may have interest in a particular subject and show apathy towards another subject. Works (1999) sees interest as a social construct developing within the dynamic relationship between the individual and the situation.

The interest a person has in a particular object is associated with that person's anxiety to know more about the object. Interest is therefore very important in almost every aspect of human endeavor. This is because it is connected to the joy one derives in whatever one is doing. Interest can therefore be defined as a person's strong leaning towards an object. This strong learning towards an object can make a person to work hard to get the object. In the context of this study interest can be linked to a student's positive disposition toward learning in general. Students are therefore expected to have interest in learning for them to succeed in their various academic endeavors.

Learning is a vital issue in education because it involves change in the behavior patterns of an individual. According to Odo (2015), learning is a process of acquiring experience, knowledge, skills and attitudes. Sanusi, Adelabu, and Okunade (2014), posits that, the idea behind every learning process is to either expand the field of experience of the learner or to see a change in the attitude or behavior of the identified persons, group, or individuals undergoing the learning. It can be deduced from this assertion that learning has to do with a change in the learner's experience or behavior. Ngwoke (2010) observes that learning causes a change in behavior of an individual, and this change in behavior results from experience or interaction between the individual and his environment.

The above observations from various authors show that learning is an indispensable aspect of education. Mckenna (2006) opines that learning covers virtually all behaviors and is concerned with the acquisition of knowledge, attitudes, values and emotional response. This implies that the aims and objectives of education cannot be said to have been achieved if learning has not taken place. According to Ayozie (2002) the primary 
objective of instruction is to bring certain desirable changes in the behavior of the learners through the process of learning. Considering the importance of learning, it can be said that all the activities in education aimed at, bringing about desirable changes in behavior revolve around learning. In the context of this study, learning is defined as the process of acquiring desirable changes in behavior. However, for learning to take place, it is important that the learner should show interest in learning. Interest in learning has to do with a student's positive attitude towards learning. A lot of factors may be responsible for students' interest in learning. For instance, a hungry student may not have interest in learning because his or her mind will be on how to eat.

Teachers' attitude towards the students or teachers' pedagogical styles may influence students' interest in learning. According to Eze (2009) the authoritarian teacher is restrictive and punitive and focuses mainly on keeping order in the classroom rather than promoting instruction and learning. In other words, teachers' activities in the classroom which include their method of teaching a particular subject or topic may either make a student to be interested in learning or develop lack of interest in learning the subject or topic. The importance of interest in learning cannot be underestimated. It a learner has interest in a particular subject or even in the teacher that teaches a particular subject, he or she is likely to record positive achievement in that subject. If, however, a student develops apathy towards a subject or the teacher that teaches it, the student will hardly do well in that subject. Interest in learning is therefore a motivating factor in the teaching and learning process.

Interest in learning may be influenced by certain activities embarked upon by students within or outside the classroom environment. This study focuses mainly on students' activities which may influence their interest in leaning especially considering the current ever increasing interest students have in the use of information and communication technology (ICT) tools. According to Agwu and Kalu (2011), the abuse of new technologies contributes to students' poor reading culture. They opined that in this era of ICT, the general orientation of young people has unconsciously changed from reading and the love of books to these technologies. They further emphasized that student's interests have changed as they now live in the generation of iPod, laptop, phone, Facebook, Twitter, and other social networking sites, thereby sacrificing reading on the altar of modern technologies. This trend is in line with the observation of Mbachu (2011) that since the advent of internet, libraries have witnessed low patronage which is a serious indication that students no longer have interest in the type of learning that will enhance their academic achievement. In support of Mbachu's observation, Nwabueze and Aduba (2014) lamented that students skip the time to engage in meaningful activities such as reading and utilizing the school library and instead engage in social networking activities such as chatting, posting pictures and watching videos. This implies that social networking has become a distraction to students. Karpinski (2009) reported that the majority of students who use Facebook every day are underachieving by as much as an entire grade compared to those who shun the site, Facebook users may feel socially successful in cyberspace but they are more likely to perform poorly in exams.

From the foregoing, it can be deduced that the young generation are very much interested in utilizing social networking sites. This may have negative impact on their interest in learning. This study therefore seeks to ascertain the influence of Twitter and Facebook on senior secondary school two (SSII) students' interest in learning. These two most popular networking sites may be utilized more in a particular area than the other. Therefore, this study also seeks to determine the influence of school location on students' interest in learning.

Location which has to do with urban and rural area might also influence students' interest in learning. For instance interest in learning is likely to be enhanced in a school environment where all the necessary teaching and learning facilities are available. School location is an important variable that affects students' academic achievement, behavior and interest in learning in almost all the school subjects. In the context of this study, school location is defined as an area where a school is situated. This may be either urban or rural. Over the years, there has been controversy on the question of whether a place where schools are located has effect on the behavior and attainment of children who attend them. According to Uzoegwu (2004), location of a school determines so many things that are important in learning such as learning facilities and environment factors, infrastructures, number and quality of teachers and the class size. Adequate provision or lack of these facilities may improve or hamper learning by students. In corroboration of this view, Igbokwe (2009) observes that where a school is located and the socio-economic environment of a school determine how well both teachers and learners realize their goals of education. The author further stated that schools in urban areas usually have better teachers and adequate instructional materials. With more ICT facilities available in the urban schools than in the rural schools, it is likely that the students in the urban schools will be more exposed to the use of social networking sites than their rural counterparts. In the context of this study, school location is defined as an area where a school is situated. This may be either rural or urban.

Some studies have however, been carried out to ascertain the effect of location on achievement of students. 
While some say that there is no basis for location differences, many are of the view that rural and urban students achieve differently. A study carried out by Akabogu (2002) on Contextual clue exposure to English registers, revealed that urban students achieved higher than rural students. Learners in rural schools have limited access to reading materials and so lack reading culture. The findings of the study further revealed that rural schools are not exposed to modern communication facilities and literate home environment and most graduate teachers are found in urban schools.

In an experiment on the effect of communication method on students' achievement and interest in Igbo letter writing, Omeje (2009) reports that urban students performed higher than rural students. However, research carried out by Uzoegwu (2004) on the effect of cooperative learning method on students' achievement in English essay writing, showed that students in rural schools achieved higher than those in the urban setting. Based on these disparities, there is need for further studies on the issue of influence of school location on students' disruptive behavior and interest in learning. The students who use these twitter and Facebook Sites are usually deeply involved in the use of these sites to the extent that they may not think of other things, including their studies.

\subsection{Relevant Studies by Previous Scholars}

Adebule and Aborishade (2013) conducted a study on influence of study interest and school location on the attitude of secondary school students towards Mathematics. The study was carried out in Ekiti State. The main purpose of the study was to find out whether the study interest and school location of students have significant influence on the attitudes of secondary school students towards Mathematics. The study employed descriptive research design of the survey type. The population of the study consisted of all secondary school students in Ekiti Sate. The sample of the study consisted of 600 students made up of 300 male and 300 female secondary school students randomly selected for the study using, multi-stage and stratified random sampling techniques. The instrument for data collection was a 28- item Mathematics Attitude Scale (MAS) constructed by the researcher. Two hypotheses were tested at 0.05 level of significance. Hypothesis one was tested using students' t-test while hypothesis two was tested using Analysis of Variance (ANOVA) and Scheffe's post-hoc test for pair wise comparison. The results of the analysis revealed, among others, that study interest has significant influence on the attitude of secondary school students towards Mathematics.

Adebule and Aborishade's study is similar to the present study because both studies have to do with secondary school students' interest in learning. However, the two studies are different in several ways. The study under review focused mainly on influence of study interest and school location on the attitude of students towards Mathematics while the present study focuses generally on influence of social networking sites on students' disruptive behavior and interest in learning. The study under review was conducted in Ekiti State while this present study was carried out in Owerri Education Zone of Imo State.

Another study was conducted by Ogbonne and Offorma (2013) on effect of collaborative learning method on secondary students' interest in English Language tenses. The study was carried out in Enugu Education Zone of Enugu State. One research question and one null hypothesis guided the study. Quasi-experimental research design was used for the study. Stratified random sampling technique was used to draw 217 senior secondary school two (SS2) students used for the study. The instrument used for data collection was the English Language Interest Inventory (ELII). Data were analyzed using mean, standard deviation and analysis of co-variance (ANCOVA). The experimental groups were taught using the collaborative learning method while the control groups were taught using the lecture method. The result showed that collaborative learning method increased the students' interest in English Language tenses more than the lecture method.

The reviewed study is related to the present study in the sense that both studies have to do with secondary school students' interest in learning. It, however differ in many ways. The study under review focused mainly on the effect of collaborative learning method on secondary school students' interest in English Language tenses while the present study focuses on influence of social networking sites on secondary school students' interest in learning. The study under review was conducted in Enugu Education Zone of Enugu State while the present study will be conducted in Owerri Education Zone of Imo State. Besides, the two studies also differ in terms of design of the study as the study under review employed the quasi-experimental research design while the present study employed the ex post-facto research design.

Furthermore, Brizimo (2014) carried out a study on the effect of drama method of instruction on the interest and achievement of secondary school students in social studies. The main purpose of the study was to investigate the effect of drama method of instruction on the interest and achievement of junior secondary school two (JSS 2) students in social studies in Bomadi Education Zone of Delta State. The study employed a quasi-experimental 
design. Specifically, pretest, post-test, non-equivalent control group design was used. The population of the study was 2,618 junior secondary school two (JSS 2) students in the 35public co-educational schools in Bomadi Education Zone in the 2013/2014 academic session. Simple random sampling technique was used to draw four schools out of these schools. The schools were randomly assigned to experimental and control groups. Students in the intact classes constituted the sample of 172 used for the study. Data were collected using a 25 - item Drama method of Achievement Test (DMAT) and a 20-item Social Studies Interest Inventory (SSII). The instrument was validated by experts from both Social Studies and Measurement and Evaluation Departments. The reliability index of 0.74 determined through Kuder-Richardson 20 formula was obtained for the DMAT while an internal consistency index of 0.91 was obtained for the SSII, using Cronbach Alpha method. Six research questions and six null hypotheses guided the study. Mean and Standard deviation were used to answer the research questions while analysis of covariance (ANCOVA) was used to test the hypotheses formulated at 0.05 level of significance. The results of the findings revealed, among others, that drama method of instruction significantly improved students' achievement in and enhanced the interest of students in Social Studies.

Brizimo's study is related to the present study because both studies have to do with secondary school students' interest in learning. Both studies, however, differ in several ways. Apart from using junior secondary school two students as the subjects, the study under review focused mainly on drama method of instruction, students' interest and achievement in social studies. The present study which used senior secondary school 11 students as subjects focused mainly on social networking sites, students' disruptive behavior and interest in learning with no particular school subject in mind. Brizimo's study employed a quasi-experimental research design while the present study employed the ex post facto research design. The study under review was conducted in Bomadi Education Zone of Delta State while the present study was carried out in Owerri Education zone of Imo State.

A study was also conducted by Ogunjinmi, Salami, and Oyedare (2015) on parents and students interest as determinants of students' academic achievement in Agricultural Science. The main purpose of the study was to find out whether different parental interests in Agricultural science as a subject and parents' socio-economic status have any influence on the academic performances of students in agricultural Science. The study employed the descriptive survey design. The sample for the study consisted of eighty secondary school students ranging from junior to senior classes in eight randomly selected secondary schools from the four Local Government Areas in Oyo metropolis, Oyo State. The instrument used for data collection was a structured questionnaire. Data collected were analyzed through the use of frequency, percentage and chi square test method. The research hypotheses were tested at 0.05 of significance. The result of the study showed that parents' interest in agricultural related activities significantly influenced students' academic performance in Agricultural Science; students' interest significantly influenced their academic performance in agricultural Science and that parents' socio-economic status did not significantly influence their interest in agricultural science.

The researchers' study is related to the present study in the sense that both studies focus on students' interest in learning. Both studies, however, differ in several ways. The study under review was conducted in some selected junior and senior secondary schools in Oyo State while the present study was conducted in selected senior secondary schools in Owerri Education Zone of Imo State. The study under review focused mainly on how parents and students interest in Agricultural science influence students' performance in Agric Science while the present study focused mainly on how social networking sites influence students' disruptive behavior and interest in learning. Both studies also differ in terms of population of the study and sample for the study.

Omeje (2009) experimented on the effect of communicative method on students' achievement and interest in Igbo letter writing. Location was one of the variables used in the study. The work employed a quasi-experimental research design. The sample consisted of 174 senior secondary school two (SS II) students from Nsukka Education Zone of Enugu State. The study was guided by six research questions and ten hypotheses. Stratified random sampling technique was used to select two schools from urban and rural areas respectively. In each of the selected schools, one arm of SSS II was randomly selected and assigned to treatment condition. While one urban school was assigned to experimental group, the other was assigned to control group. The same was done for the rural schools. The experimental group was taught with communicative teaching method while the control group was taught with the conventional lecture method. Letter writing Achievement Test (LWAT) and Igbo Language Interest Inventory (ILII) were the instruments used for data collection. The data we analyzed using the Analysis of Covariance (ANCOVA). The findings showed that students taught letter writing with communicative teaching method achieved higher than those taught with conventional method. Also, urban students performed better than rural students in letter writing.

Omeje's study is similar to the present study in terms of the use of location as one of the variables. Both studies, however, differ in terms of area of the study, design of the study, instruments for data collection, number of 
research questions and hypotheses and based on the fact that the study under review focused on letter writing on Igbo language while the present study focuses on learning in general.

It is based on the foregoing background that the researchers carried out the present study. Specifically, the study addressed the following purposes.

1) Ascertain the influence of facebook and twitter social networking sites' activities on students' interest in learning.

2) Determine the influence of location on students' interest in learning.

The study answered the following research questions.

1) What is the influence of facebook and twitter social networking sites' activities on students' interest in learning?

2) What is the influence of location on students' interest in learning?

\subsection{Statement of Hypotheses;}

The following null Hypotheses were stated and applied in line with the research design.

$\mathrm{Ho}_{1}$ : There is no significant influence between students' social networking sites' activities and their interest in learning.

$\mathrm{Ho}_{2}$ : There is no significant difference in the mean interest ratings of urban and rural students.

\section{Method}

\subsection{Design of the Study}

In carrying out this study, the researchers applied ex-post facto research design. In this type of design, the independent variable cannot be manipulated because it already exists. In this case the independent variables are twitter, Facebook and location which are already in existence and cannot be manipulated by any researcher. According to Nworgu (2015) ex post Facto design is appropriate wherever the independent variables cannot be manipulated.

The study was carried out in Owerri Education zone. This zone is located in the South East of Nigeria. There are three zones in Imo State, which include Orlu, Okigwe, and Owerri zones. Altogether there are twenty-seven Local Government Areas in Imo State. Abor Mbaise is one of the Local Government Areas in Owerri zone. The researchers chose this area because most of the secondary school students are more interested in internet connections than settling down to read their books and even find it very difficult to do their homework.

\subsection{Participants Characteristics}

The population of the study is made up of one thousand seven hundred and fifty-seven $(1,757)$ senior secondary II students. The choice of the senior secondary 11 students was based on the fact that they were not in examination classes. Above all they are not preparing for any external examination and so had time to co-operate in responding to the questionnaire.

\subsection{Sampling Procedure}

\subsubsection{Sample Size, and Precision}

Multi-stage sampling technique was applied to select 240 SSII students for the study. At the first stage out of the six zones in Nigeria, one zone which is the South East Zone was selected. Secondly, Owerri Education Zone which is one of the educational zones in Imo State located in the South East Zone was selected. This educational zone is made up of nine (9) local government Areas. Abor Mbaise which is one out of the nine local Government Areas was selected. This Local Government Area is made up of eleven (11) secondary schools, five from urban and six from rural areas. In sampling, the researchers adopted the National Education Association Technique in Krejcie and Morgan (1970) in selecting the subjects. These authors stated that when the population is between 1000 and 2500, the sample size should range between 240 and 246 Therefore, going by this, the sample of the study which is 240 is appropriate for the study.

\subsubsection{Research Design}

In carrying out this study, the researchers applied ex-post facto research design. In this type of design, the independent variable cannot be manipulated because it already exists. In this case the independent variables are twitter, Facebook and location which are already in existence and cannot be manipulated by any researcher. According to Nworgu (2015) ex post Facto design is appropriate wherever the independent variables cannot be 
manipulated.

\subsubsection{Procedure Manipulation}

A 15-item questionnaire constructed by the researcher was used in data collection. The instrument was constructed on a 4 - point rating scale ranging from Strongly Agree (SA) rated 4, Agree (A) rated 3, Disagree (D) rated 2 and Strongly Disagree (SD) rated 1. The instrument was subjected to face validation by three experts from the Faculty of Education, University of Nigeria, Nsukka. These include two from the Department of Educational Foundations and one from Science Education (Measurement and Evaluation) unit. The initial drafts of the instruments were submitted to the experts. They were requested to study the items and assess the relevance and clarity of the items in addressing the research questions. Their corrections and comments were strictly adhered to in the modification of the items. In answering the research questions, Mean and Standard Deviation were used while t-test was used to test the null hypotheses.

\section{Results}

Table 1. Mean analysis of the influence of the Twitter and Facebook activities on students' interest in learning

\begin{tabular}{cccc}
\hline Site Activities & $\mathrm{N}$ & Mean & Std. Deviation \\
\hline Twitter & 240 & 3.00 & .39 \\
Facebook & 240 & 2.83 & .51 \\
\hline
\end{tabular}

Table 1 shows the mean analysis of the influence of twitter and Facebook activities on the students' interest in learning. It shows that the students who engage in twitter activity had mean interest of 3.00 with standard deviation of 0.39 while their engagement in Facebook activity had mean interest of 2.83 with standard deviation of 0.51 . This may be an indication that the students' engagement in twitter activity may have made them to have higher mean interest in learning than their engagement in Facebook activity.

Table 2. Mean and standard deviation of the ratings of students based on students' location and interest in learning

\begin{tabular}{|c|c|c|c|c|c|c|c|}
\hline \multirow[b]{2}{*}{ SN } & \multirow[b]{2}{*}{ Item } & \multicolumn{3}{|c|}{ Urban $\mathrm{N}=120$} & \multicolumn{3}{|c|}{ Rural $\mathrm{N}=120$} \\
\hline & & $\bar{x}$ & $\mathrm{SD}$ & Remarks & $\bar{x}$ & $\mathrm{SD}$ & Remarks \\
\hline 1 & I like being in the class during lessons & 2.75 & .83 & Agree & 2.77 & .90 & Agree \\
\hline 2 & I enjoy listening attentively when lesson is going on & 2.70 & .84 & Agree & 2.86 & .89 & Agree \\
\hline 3 & I like asking questions during class & 2.90 & .84 & Agree & 2.95 & .90 & Agree \\
\hline 4 & Being passive in the class during lessons makes me feel comfortable & 3.19 & .61 & Agree & 3.15 & .71 & Agree \\
\hline 5 & If feel happy whenever I am called upon by my teacher to difficult concepts & 3.14 & .62 & Agree & 3.14 & .66 & Agree \\
\hline 6 & I like answering questions asked by my teachers in the class & 3.10 & .62 & Agree & 3.00 & .64 & Agree \\
\hline 7 & I enjoy writing tests and assignments & 3.04 & .70 & Agree & 3.05 & .67 & Agree \\
\hline 8 & I like discussing difficult concepts with my classmates & 2.85 & .78 & Agree & 2.83 & .75 & Agree \\
\hline 9 & I like being taught with computers & 2.72 & .77 & Agree & 2.79 & .81 & Agree \\
\hline 10 & I enjoy contributing my own ideas during lessons & 2.65 & .78 & Agree & 2.77 & .82 & Agree \\
\hline 11 & Being absent from school makes me feel unhappy & 2.78 & .81 & Agree & 2.85 & .85 & Agree \\
\hline 12 & I usually encourage my classmates to take active part in lessons & 2.88 & .82 & Agree & 2.85 & .76 & Agree \\
\hline 13 & I like studying all school subjects & 2.97 & .81 & Agree & 2.92 & .82 & Agree \\
\hline 14 & I like studying only the Science subjects & 2.81 & .75 & Agree & 2.89 & .78 & Agree \\
\hline \multirow[t]{2}{*}{15} & I like studying only the Arts subjects & 2.83 & .74 & Agree & 2.95 & .79 & Agree \\
\hline & Overall Mean & 2.92 & .50 & Agree & 2.89 & .47 & Agree \\
\hline
\end{tabular}

Table 2 shows the mean ratings of students on the influence of location on their interest in learning. It shows that the mean ratings of urban and rural students to items 1 to 15 are more than the generally accepted 2.50 bench mark mean. Thus, both students in urban and rural school locations agree to the statements of the items. However, the overall mean ratings of 2.92 and 2.89 for the students in urban and rural school locations respectively, imply that the students in urban school location have higher mean interest in learning than those in rural school location. 
Table 3. T-test analysis of Twitter and Facebook activities based on their interest in learning

\begin{tabular}{ccccccc}
\hline Site Activities & Number & Mean & Std. Deviation & Df & t-cal & Sig. (2-tailed) \\
\hline Twitter & 240 & 3.00 & .39 & 238 & \multirow{2}{*}{7.310} & .000 \\
Facebook & 240 & 2.83 & .51 & & & \\
\hline
\end{tabular}

Table 3 shows that the probability associated with the calculated value of $t$ (7.310) for the influence of social networking sites' activities on students' interest in learning is 0.000 . Since the probability value of 0.000 is less than the 0.05 level of significance, the null hypothesis is rejected. This implies that there is a significant influence of students' social networking sites' activities on their interest in learning in favor of the twitter activity.

Table 4. T-test analysis of students' responses based on location

\begin{tabular}{ccccccc}
\hline Location & Number & Mean & S.D & Df & t-cal & Sig. (2-tailed) \\
\hline Urban & 120 & 2.92 & .50 & \multirow{2}{*}{238} & -.483 & .630 \\
Rural & 120 & 2.89 & .47 & & & \\
\hline
\end{tabular}

Table 4 shows that the associated probability for the calculated value of $t(-0.483)$ for the influence of location on students' interest in learning is 0.630 . Since the probability value of 0.630 is greater than the 0.05 level of significance, the null hypothesis was accepted. This means that there is no significant difference in the mean interest ratings of urban and rural students.

\section{Discussion of the Findings}

There is a significant influence of students' Twitter and Facebook activities on their interest in learning in favor of the students' engagement in twitter activities. This implies that since the students have interest in the use of twitter, their interest in learning can be enhanced if the teachers use twitter in teaching them. This is because students learn more when they have interest in what is being taught during the teaching and learning processes. The findings revealed that students in urban school location have higher mean interest rating than their counterparts in the rural school location. Further analysis showed that there is no significant difference in the mean interest ratings of urban and rural students. In other words, both urban and rural school students were almost at par in their interest in learning. Students in urban school locations had higher mean interest in learning than those in rural school locations. Further analysis showed that there is no significant difference in the mean interest ratings of urban and rural students.

This may have indicated that the students' engagement in twitter activity make them to have higher mean interest in learning than their engagement in facebook activity. This finding is in line with that of Smith and Tirumala (2012) whose study indicated that students exposed to the use of twitter perceived twitter as more useful in the classroom than did participants who did not use twitter. Besides, twitter made learning more fun and interesting as it increased students' social comfort of expression.

The result of this study on interest is in consonance with Torty (2010) who did not establish any significant difference in the mean interest rating scores of students in urban and rural schools in English language tenses. The higher mean interest rating recorded by students in the urban area could have arisen from the fact schools in the urban areas have qualified and dedicated teachers in great supply.

\section{Conclusion and Recommendations}

The findings indicated that the students in urban areas recorded higher mean interest rating than their counterparts in the rural areas. This could have arisen from the fact that schools in the urban areas have better learning facilities and qualified and dedicated teachers in great supply. The onus lies on the government to equip the rural schools with adequate learning facilities and qualified teachers to reduce the gap in this regard. For curriculum developers, the findings of this study imply that there is the need to incorporate the use of twitter as one of the innovative approaches to the teaching of different subjects at the secondary school level, in the next curriculum review. Teachers should enhance their pedagogical skills to be able to incorporate the use of twitter in the teaching and learning process since it has been observed that students have interest in its use. Curriculum developers should incorporate the use of Social Networking Sites, especially twitter, in the teaching of different school subjects in secondary schools in order to enhance students' interest and achievement in learning. School administrators, both in the urban and rural areas, should endeavor to put disciplinary control measures in place in 
order to ensure that students' activities are monitored.

\section{Acknowledgements}

Our gratitude goes to Dr. Agah, who analyzed the data for this article. Our immeasurable thanks go to Chukwuma Igbo who helped to send this article, in spite of series of problems in network connection. We appreciate the help rendered by our senior colleagues who contributed through their selfless suggestions, encouragement, and corrections rendered throughout the process of writing this article.

\section{References}

Adebule, S. O., \& Aborishade, S. (2016). An investigation on secondary school students' attitude towards science in Ogon State, Nigeria. Journal of Education and Practice, 28(7), 1-4.

Agwu, G. O., \& Kalu, A. U. (2011). Information for all: Towards promoting reading culture and leadership for national development in Nigeria. Ibadan: Nigerian Library Association.

Akabogu, J. U. (2002). An effect of secondary school students' exposure to English registers contextual clues on achievement in reading comprehension (Unpublished Ph.D thesis). Faculty of Education, University of Nigeria, Nsukka.

Akpan, U., Enebong, A., \& Nsikam, S. (2013). Uses and gratifications of social networking websites among youths in Uyo. Nigeria International Journal of Nigerian Social Science, 3(2), 353-369.

Alibi, O. F. (2013).A survey of Facebook addiction level among selected Nigerian University Undergraduates. New media and mass Communication, 10(13), 70-80.

Anizoba, E. N. (2004). The effects of the writing process method on students' performance in English composition (Unpublished PhD thesis). University of Nigeria, Nsukka.

Arshin, A. (2010). The effects of social networking sites like Facebook. Retrieved from http://www.studymode.com/index-and roid.html

Azeez, K. (2011). Addiction of blackberry spread in Nigeria. Could become major cause of insomnia, motor accident, possible brain tumor, experts warm.

Brizimo, M. (2014). Effect of drama on the interest and achievement of junior secondary school students. University of Nigeria, Nsukka. Institutional Repository.

Chukwu, J. O. (2002). Promoting interest in mathematics learning through local games. International Journal of Arts and Technology Education, 2(1), 124-136.

Csikszentmihalyi, M. (1975). Beyond boredom and anxiety. San Francisco: Jossey-Bass.

Igbokwe, U. L. (2009). Overview of curriculum. In U. L. Igbokwe, \& U. N. Eze (Eds.), Classroom management for curriculum implementation. Applying psychological principles. Enugu: Timex publishers.

Karpanski, A. (2009). Facebook fans do worse in exams. Retrieved from http://www.mathhope.edu/stats/articles/facebook.gpa.pdf

Krejcie, R. V., \& Morgan, D. W. (1970). Determining sample size for research activities. Educational and Psychological Measurement, 30, 607-610. https://doi.org/10.1177/001316447003000308

Kuss, D., \& Griffiths, M. (2011). Online social networking and addiction. A review of the psychological literature. International Journal of Environmental Research and Public Health, 8, 3528-3352. https://doi.org/10.3390/ijerph8093528

Lai, Q. (2010). A survey of national Taoyuan senior-high school students' interest in learning music and demand for self s-decision. Taiwan: Department of music National Taiwan Normal University.

Li, X. L. (2009). A study of the attitude and sense of self-efficacy of mother tongue teachers at public kindergartens in chiayi country/city. Taiwan: Graduate Institute of Early Childhood Education, National/Chiayi University.

Mbachu, G. (2011). Internet and declining reading culture in Nigeria. Punch Newspaper, 29, 33.

McCartthy, J. (2009). Utilizing Facebook: Immersing generation students into first years.

Mclaughin, C., \& Vitak, J. (2012). Norm evolution and violation on facebook. New Media \& Society, 10, 1-17.

Morgan, N., Graham, J., \& Hodges, A. (2012). Social media. The complete guide to social media. Retrieved from http://www.Thesocialmediaguys.co.uk/wp/content/uploads/downloads/2011/03/completeGuideto 
Socialmedia.pdf

Nworgu, B. G. (2015). Educational research. Basic issues and methodology. Ibadan: Wisdom Publishers Ltd.

Ogbonne, T., \& Offorma, G. C. (2013). Effect of collaborative learning method on secondary students' interest in English language tenses. International Journal of Educational Research, 12(2), 128-135.

Ogunjimi, O., Salami, T., \& Oyedare, O. (2015). Parents and student's interest as determinants of student's academic performance in Agricultural Science in selected secondary schools in Oyo Metropolis, Oyo State. International Journal of Academic Research in Progressive Education and Development, 4(4), 11-20.

Omeje, M. O. (2009). Effects of communicative method on students' achievement and interest in Igbo letter writing (Unpublished $\mathrm{PhD}$ thesis). University, of Nigeria, Nsukka.

Omeraka, J. O. (2009). Teachers' utilization of secondary school libraries. A survey study of Idah Local Government Area of Kogi State (Unplished M.Ed. thesis). University of Nigeria, Nsukka.

Ovute, A. O., \& Ovute, L. E. (2015). Effect of social media on secondary school students acquisition of knowledge. International Journal of Current Research and Academic Review, 3(5), 81-91.

Smith, J. E., \& Tirumala, L. N. (2012). Twitter's effects on student learning and social presence perceptions. Teaching Journalism and Mass Communication, 2(1), 21-31.

Torty, O. U. (2010). Effect of collaborative learning method on secondary school students' academic achievement and interest in English Language tenses (Unpublished $\mathrm{PhD}$ thesis). University of Nigeria, Nsukka.

Uzoegwu, P. N. (2004). The effect of cooperative learning method on students' achievement in English essay writing (Unpublished $\mathrm{PhD}$ thesis). University of Nigeria, Nsukka.

Van-Vooren, C., \& Bess, C. (2013). Teacher tweet improve achievement for eight grade science students. Cybernenetics and Informatics, 11(1), 33.

\section{Copyrights}

Copyright for this article is retained by the author(s), with first publication rights granted to the journal.

This is an open-access article distributed under the terms and conditions of the Creative Commons Attribution license (http://creativecommons.org/licenses/by/4.0/). 